\title{
A Lei n'. 3.780, de 1960, e as Funções Gratificadas
}

$U_{M}$ dos aspectos mais controvertidos da aplicação da Lei $n .^{\circ} 3.780$, de 1960, tem sido o que se refere à classificação das funções gratificadas, cujo conceitc foi integralmente mantido, mas que sofreram fundamental modificação no que diz respeito aos critérios adotados para a fixação dos respectivos simbolos.

De fato, na sistemática administrativa brasileira, levava-se em conta, na fixação dêsses simbolos, a identidade de atribuições, tão sòmente, não se cogitando, senão em poucas oportunidades, de outros fatôres, que a Lei 3.780 de 1960 veio tornar relevantes para o equacionamento da questão.

$E^{\prime}$ tradicional o conceito de que a função gratificada de chefia, de secretariado e de assessoramento é, nada mais nada menos, do que uma compersação pecuniária, paga sob a forma de gratificiçãa de função, e como vantagem. aos que executam êsses encargos, previstos, necessàriamente, nos regimentos das diversas repartiçóes - recebendo o servidor o vencimento do cargo cumulativamente com a gratificicação pelo exercicio da função.

A Lei 3.780, de 1960, ao tratar, em seu Capitulo II, das referidas funções, inovou, completamente, a questão, quando dispôs:

“Art. 12. O Poder Executivo regulamentará a classificação das funções gratificadas com base, entre outros, nos principios de hierarquia funcional, analogia das funçóes, importância, vulto e complexidade das respectivas atribuiçôes.

Parágrafo único. Nesta regulamentação, deverá ser prevista também a correlação fundamental entre as atribuições do cargo efetivo do funcionário e da função gratificada para que fôr designado a exercer.

Art. 13. A gratificação de função será calculada na base dos simbolos e valores constantes do item C do Anexo III. 
Parágrafo único. A importância da gratificação de função será igual à diferença entre o valor estabelecido para o simbolo respectivo e o vencimento do cargo efetivo exercido pelo funcionário.

Estabelecendo a obrigatoriedade de na sua classificação, serem levados em conta o vulto e a complexidade das respectivas atribuições, estabeleceu sensivel diferença, no que diz respeito ao "quantum" da gratificação, entre funções gratificadas até agora escalonadas no mesmo nivel.

Determinando que a gratificação da função corresponderá à diferença entre o valor estabelecido para o simbolo respectivo e o vencimento do cargo efetivo do servidor, tornout importante a correlação e estabeleceu, também por essa forma, ponderável diversificação entre funções até agora tratadas igualmente.

Empiricamente classificadas têm as funções gratificadas, face aos novos critérios, mandados adotar pela Lei 3.780, de 1960, e esclarecidos pelo decreto regulamentador $n^{9}$ 49.592, de 27 de dezembro de 1960, que obedecer, na fixação de setts simbolos, à hierarquia funcional (pelo simbolo do cargo em camissão a que se subordinar e que indica a posição da mesma na escala administrativa), à importância (pela situação orçamentátia da unidade administrativa bem como pela influência na execução da politica governamental), ao vulto (pelo número de cargos lotados) e à complexidade (pelo nivel dêsses cargos).

Termina, assim, com a vigência da Lei 3.780, de 1960, o periodo em que influências pessoais levavam determinadas funções gratificadas a uma classificação inteiramente em desacôrdo com suas reais atribuições, classificando-se, assim, seus eventuais ocupantes e não elas próprias.

Revolucionando o sistema, o novo diploma legal com todos os erros naturais que as mudanças acarretam, é um valioso instrumento para a Administraçãc que desejar fixar, em justos e eqüitativos têrmos, o valor das mesmas. 